\title{
US scientists rally around call for seven per cent
}

\section{UNAVAILABLE FOR COPYRIGHT REASONS}

Slipping behind: Russia's Mir craft is predecessor of its planned contribution to the space station.

\section{NASA head predicts space station delay}

[WASHINGTON] US officials expect construction of the international space station to begin at least six months after the original target date of November because of delays in Russian financing of a critical module. The 'service' module is intended to keep the station in orbit during the early stages of assembly and to house its initial crew.

Although the schedule slip had not been officially announced by Daniel Goldin, the head of NASA, by the beginning of this week, he has told a congressional committee that he anticipated a delay.

Goldin's reluctant admission came during a week of confusion and increased criticism of Russia's role in the project. Yuri Koptev, the head of the Russian space agency, announced that launch of the station's "first element" - on a Russian rocket - would slip until June 1998. But a surprised NASA official quickly dismissed that as premature.

Although Russian prime minister Viktor Chernomyrdin promised last month that his government would release money to Russian contractors building station hardware by the end of February, "it appears that's slipping into March," said a NASA spokesperson.

James Sensenbrenner (Republican, Wisconsin), chairman of the House of Representatives science committee, returned recently from a fact-finding trip to Russia frustrated at the lack of progress on the service module and the ever-receding deadlines. White House and NASA officials have been more patient, seeing Russian participation as part of a larger foreign policy initiative to engage that country's scientists and engineers.

Sensenbrenner and others fear political damage to the programme caused by delays and possible cost overruns should the Russians default. Marcia Smith, a space policy expert with the Congressional Research Service, warned Sensenbrenner's committee last month that NASA's attempts to produce last-minute contingency plans to replace the Russian service module are "only one example of the technical confusion surrounding the space station today".

Tony Reichhardt
[WASHINGTON] Professional societies representing more than a million US scientists, engineers and mathematicians have joined forces to call for a budget increase "in the range of seven per cent" for research at all major science-funding agencies in the federal government.

The statement, addressed to President Bill Clinton and the Congress, and due to be released at a press conference on Tuesday (4 March) of this week, is signed by 23 societies, including the main organizations representing physicists, chemists, earth scientists, mathematicians, and electrical engineers.

But biomedical researchers, who are campaigning for a larger increase in funding for the National Institutes of Health (NIH), did not join in the exercise, fracturing the otherwise united front which the societies are seeking to present.

Nonetheless, Allan Bromley, president of the American Physical Society (APS) and dean of engineering at Yale University, said that the community had achieved "unprecedented unity" in agreeing on the joint statement. Bromley says he is "increasingly optimistic" that message will be heard: both houses of Congress, he says, are starting to view investment in science more favourably.

The joint statement says that increases of around seven per cent would "strike a fair balance between current fiscal pressures and the need to invest in activities that enable long-term growth" and that they would "partially restore the inflationary losses that most agencies have suffered during the last few years".

Arthur Jaffe, president of the American Mathematical Society (AMS), said that the budget for the 1998 financial year proposed by President Bill Clinton (see Nature 385, 565 ; 1997) does not keep up with inflation, and is therefore "inconsistent with president Clinton's goals" as stated in the president's State of the Union address. Clinton's budget, which will be considered by the Congress between now and October, calls for increased research spending of around two per cent.

The joint statement springs from an effort which was initiated late last year by the American Chemical Society (ACS), the Federation of American Societies for Experimental Biology (FASEB), and the APS to better co-ordinate their lobbying activities (see Nature 384, 393; 1996).

But according to sources at several of the societies, FASEB, which represents biomedical researchers, had wanted to restrict the joint initiative to support for the National Science Foundation. The organization is said to have been concerned that a call for increases across all agencies was unrealistic, and that the call for seven per cent would undermine its own campaign for a nine per cent increase at the NIH.

ColinMacilwain

\section{India proposes first increase for six years}

[NEW DELHI] In India's first 'science-friendly' budget for six years, the government has proposed increasing spending on science by 11 per cent next year, and has launched a scheme to encourage outstanding Indian scientists to carry out world-class research.

The budget for 1997-98, placed before parliament last week, also gives a boost to research in industry, while providing money to modernize the 40 laboratories of the Council of Scientific and Industrial Research (CSIR).

India's scientists will have about US $\$ 200$ million more to spend on research than this year. The research community has welcomed the budget, which provides $\$ 1,760$ million for science-related activities, as well as $\$ 192$ million for nuclear-power schemes.

In addition, the government is proposing to set aside \$14.2 million "to assist outstanding scientists under the age of 45 to attain and sustain world class science". The move, intended to stem India's brain drain, was prompted by concern about "declining interest in sciences in school and colleges".

As well as an across-the-board increase in funding for all scientific departments, the government has offered to match any private-sector funding raised by the national laboratories.

In future, publicly funded research institutions will be able to invest their knowledge as equity in private-sector companies. Scientists have also welcomed a decision to reduce customs duty and waive excise duty on scientific equipment.

As in previous years, the largest parts of the science budget will go on space, atomic energy and defence research. The space department has been promised funds to start work on a direct-to-home broadcasting satellite system.

But oceanographic research has won a 75 per cent boost. In the area of health, funds for malaria control have gone up by 30 per cent while support for AIDS prevention will drop from $\$ 40$ million last year to $\$ 28$ million this year.

K.S. Jayaraman 